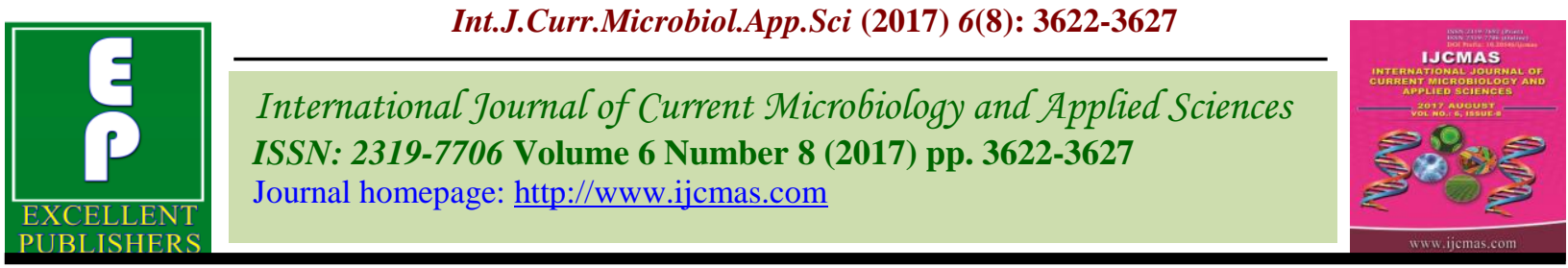

Original Research Article

https://doi.org/10.20546/ijcmas.2017.608.436

\title{
Azolla - A Low Cost and Effective Feed Supplement to Poultry Birds
}

\author{
A. Lakshmanan ${ }^{1 *}$, K. Kumar ${ }^{2}$ and P. Latha ${ }^{1}$ \\ ${ }^{1}$ Department of Rice, ${ }^{2}$ Department of Agricultural Microbiology, Tamil Nadu Agricultural \\ University, Coimbatore-641 003, Tamil Nadu, India \\ *Corresponding author
}

\begin{tabular}{|c|c|}
\hline & A B S T R A C T \\
\hline & $\begin{array}{l}\text { A study was conducted to evaluate the utility of Azolla as a feed supplement to poultry } \\
\text { birds. Two species of azolla viz., A. microphylla and A. filiculoides and two Azolla hybrids }\end{array}$ \\
\hline Keywords & $\begin{array}{l}\text { viz., Rong ping and TNAU1 were initially analyzed for their nutritional parameters so as to } \\
\text { select the suitable Azolla species to feed the poultry birds. Azolla hybrids Rong ping and }\end{array}$ \\
\hline $\begin{array}{l}\text { Azolla hybrids, } \\
\text { Nutrient } \\
\text { supplementation, } \\
\text { Productivity, } \\
\text { Poultry birds. }\end{array}$ & $\begin{array}{l}\text { TNAU1 recorded higher biomass production than wild Azolla cultures. A maximum } \\
\text { protein content of } 318.20 \mu \mathrm{g} / \mathrm{mg} \text { dry weight was recorded by the Azolla hybrid Rong ping. } \\
\text { The Azolla hybrid Rong ping also showed maximum carotenoid }(2.01 \mu \mathrm{g} / \mathrm{mg}) \text { and } \beta \\
\text { carotene }(0.64 \mu \mathrm{g} / \mathrm{mg}) \text { content. The layer birds fed with Azolla hybrid Rong ping } \\
\text { registered an overall egg productivity of } 89.0 \% \text { as against } 84.0 \% \text { recorded by the birds fed }\end{array}$ \\
\hline Article Info & with only concentrated feed. The average daily intake of concentrated feed in the birds fed \\
\hline $\begin{array}{l}\text { Accepted: } \\
\text { 27 June } 2017 \\
\text { Available Online: } \\
10 \text { August } 2017\end{array}$ & $\begin{array}{l}\text { total protein content of the eggs laid by the Azolla fed birds was high }(14.0 \mathrm{~g} / 100 \mathrm{~g} \text { of } \\
\text { edible portion) and the total carotene content of these eggs ( } 440 \mu \mathrm{g} / 100 \mathrm{~g} \text { of edible } \\
\text { portion) was also higher than the control. The increase in egg productivity, nutritional } \\
\text { value and savings in the concentrated feed clearly indicated the suitability of Azolla as a } \\
\text { potential feed supplement for poultry birds. }\end{array}$ \\
\hline
\end{tabular}

\section{Introduction}

Azolla is a free floating water fern that floats in water and fixes atmospheric nitrogen in association with the nitrogen fixing blue green alga, Anabaena azollae. Azolla is considered to be a potential biofertilizer in terms of nitrogen contribution to rice crop (Kannaiyan, 1992). Long before its cultivation as a green manure, Azolla was used as a fodder for domesticated animals such as pigs and ducks.

In recent days, Azolla is very much used as a sustainable feed substitute for livestock especially dairy cattle, poultry, piggery and fish. Azolla contains $25-35 \%$ protein on dry weight basis and rich in essential amino acids, minerals, vitamins and carotenoids including the antioxidant $\beta$ carotene (Ivan et al., 1989). Chlorophyll $a$, chlorophyll $b$ and carotenoids are also present in Azolla, while the cyanobiont Anabaena azollae contains chlorophyll $a$, phycobiliproteins and carotenoids (Tyagi et al., 1980). Azolla is used as a fodder in North Vietnam, Asia, Africa and China (Anonymous, 1985) and the rare combination of high nutritive value and rapid biomass production make Azolla a potential and effective feed substitute for livestock, particularly poultry birds. Hence, a study was conducted to evaluate the utility of Azolla as a feed supplement to poultry birds. 


\section{Materials and Methods}

Two species of Azolla viz., A. microphylla and A. filiculoides and two Azolla hybrids viz., Rong ping and TNAU1 were analyzed for their nutritional parameters such as protein, carotenoids and $\beta$ carotene contents and also for their biomass production potential so as to choose the suitable Azolla culture to feed the poultry birds.

The biomass production, doubling time and relative growth rate of the selected Azolla cultures were estimated both under field and laboratory conditions. Fresh fronds of Azolla were washed well, blot dried and inoculated @ $500 \mathrm{mg}$ on fresh weight basis in $250 \mathrm{ml}$ conical flasks, each containing $100 \mathrm{ml}$ of nitrogen free IRRI medium (Watanabe,1977).

The conical flasks containing the Azolla were kept in a growth chamber at $28 \pm 1{ }^{\circ} \mathrm{C}$ temperature with a light intensity of 3,000 lux for 15 days period. To estimate the biomass production of different Azolla cultures under field conditions, fresh Azolla fronds were inoculated in cement tanks@100 g/ $\mathrm{m}^{2}$ and allowed to grow for a period of 15 days by maintaining the optimum growth condition.

After 15 days the weight of the fresh biomass was assessed and from the weight of the initial and final biomass, the doubling time and relative growth rate were calculated following the method of Subudhi and Watanabe (1981).

Doubling time $(\mathrm{DT})=\mathrm{t} / \mathrm{r}$

Where,

$\mathrm{t}=$ Experimental period

$r \quad=\quad \frac{\log \left(\mathrm{W}_{1}-\mathrm{W}_{0}\right)}{---{ }^{\prime}}$
Where,

$\mathrm{W}_{1}=$ Weight after ' $\mathrm{t}$ ' days

$\mathrm{W}_{0}=$ Weight of initial inoculum

$0.301=$ Constant

The relative growth rate was estimated using the formula,

RGR $=0.693 /$ doubling time

Where, 0.693 is a constant.

The carotenoid content of Azolla was estimated calorimetrically by the method of Siegelman and Kycia (1976) and the $\beta$ carotene content was estimated by High performance liquid chromatography using $\mathrm{C}_{18}$ column. The total protein content was estimated as suggested by Lowry et al., (1957).

To find out the utility of Azolla hybrid Rong ping as a feed supplement to poultry birds, fresh Azolla fronds were top dressed to a batch of fifty birds which were fifty one weeks old @ 10.0 g per bird per day as single dose along with concentrated feed of standard composition.

A control batch of fifty birds of same age was maintained which were fed only with concentrated feed. The feed intake, feed left over and egg production were recorded periodically in both the batches of Azolla fed birds and control birds fed with only standard concentrated feed.

The experiment was continued for a period of 17 weeks starting from $51^{\text {st }}$ week of age to $67^{\text {th }}$ week. To find out the effect of Azolla consumption on the nutritive value of the egg, individual egg weight, albumin and globulin content were estimated in eggs laid by Azolla fed birds and birds fed only with concentrated feed. 


\section{Results and Discussion}

\section{Biomass production and nutritional value of different Azolla culture}

Among the different Azolla species tested for the biomass production, Azolla hybrids Rong ping and TNAU1 recorded higher biomass production than wild Azolla cultures as shown in table 1.

Azolla hybrid Rong ping recorded the maximum biomass production (3.11 g), followed by TNAU1 hybrid (2.82 g) when grown in growth chamber under controlled condition and the similar trend was also noticed under field condition.

The Azolla hybrid Rong ping recorded a doubling time of 5.39 and 5.02 days under laboratory and field conditions respectively.

Among the four Azolla species tested, Azolla hybrid Rong ping registered the maximum relative growth rate of $0.129 \mathrm{~g} / \mathrm{g} / \mathrm{d}$ under laboratory condition.

Based on the growth conditions, Becking (1979) recorded a doubling time of 2.0 to 19.9 days in different Azolla species. Kannaiyan (1988) observed a doubling time of 3.1 days in A. mexicana and A. filiculoides.

While estimating the protein content of the Azolla species under study, a maximum protein content of $318.20 \mu \mathrm{g} / \mathrm{mg}$ dry weight was recorded by the Azolla hybrid Rong ping. Among the wild Azolla cultures, A. microphylla recorded higher $\beta$ carotene content than A. filiculoides and among the hybrids Rong ping showed maximum carotenoid $(2.01 \mu \mathrm{g} / \mathrm{mg}$ dry weight $)$ and $\beta$ carotene $(0.64 \mu \mathrm{g} / \mathrm{mg}$ dry weight $)$ content and thus proved its suitability as a feed supplement to poultry birds.
Feeding effect on Azolla hybrid Rong ping on the productivity

The data on the egg yield showed that in the layer birds fed with Azolla hybrid Rong ping, increased egg yield was noticed due to Azolla feeding (Table 2). The Azolla fed birds registered an overall egg productivity of $89.00 \%$ as against $83.70 \%$ recorded by the birds fed with only concentrated feed. The average daily intake of concentrated feed was considerably low (106 g) for birds due to Azolla substitution as against $122 \mathrm{~g}$ in the control birds. More importantly Azolla feeding showed considerable amount of savings in the consumption of concentrated feed $(13.0 \%)$ leading to reduced operational cost. By considering the average cost of the concentrated feed as Rs. $8.17 / \mathrm{Kg}$, a $13.0 \%$ saving in the consumption of concentrated feed due to Azolla supplementation ultimately leads to a feed cost saving of 10.0 paise/day/bird and hence a layer unit maintaining 10,000 birds could cut down its expense towards feed to a tune of Rs.1000/day. Anon (1985) reported that in dried form Azolla can be substituted for 15$20 \%$ of the starchy feed required for pigs. Anon (1985) also reported that live stock gained weight faster when fed with Azolla rice straw mixture.

\section{Rong Ping effect on the nutritional value}

While analyzing the nutritional value of the egg laid by the birds fed with Azolla, increased egg weight $(61.20 \mathrm{~g})$, higher albumin, globulin and carotene contents were noticed (Table 3). Sundararaju et al., (1995) investigated the effect of feeding Azolla, Sesbania and Leucaena proteins on the performance of broiler chicken. They found that that the dried Azolla, Sesbania and Leucaena meals when fed to broiler chicken at $6 \%$ level significantly increased the body weight at 4,6 and 8 weeks of age. 
Table.1 Biomass production and nutritional value of different Azolla cultures

\begin{tabular}{|c|c|c|c|c|c|c|c|c|c|}
\hline \multirow{2}{*}{ Azolla cultures } & \multicolumn{2}{|c|}{$\begin{array}{c}\text { Biomass* } \\
(\mathrm{g})\end{array}$} & \multicolumn{2}{|c|}{$\begin{array}{c}\text { Doubling } \\
\text { time (days) }\end{array}$} & \multicolumn{2}{|c|}{ RGR (g/g/d) } & \multirow{2}{*}{$\begin{array}{c}\text { Protein } \\
(\mu \mathrm{g} / \mathrm{mg}) \\
\text { dry } \\
\text { weight }\end{array}$} & \multirow{2}{*}{$\begin{array}{c}\text { Carotenoids } \\
(\mu \mathrm{g} / \mathrm{mg}) \\
\text { dry weight }\end{array}$} & \multirow{2}{*}{$\begin{array}{c}\beta \\
\text { carotene } \\
(\mu \mathrm{g} / \mathrm{mg}) \\
\text { dry } \\
\text { weight }\end{array}$} \\
\hline & Lab & Field & $\mathrm{Lab}$ & Field & $\mathrm{Lab}$ & Field & & & \\
\hline A. microphylla & 2.71 & 715.0 & 5.60 & 5.40 & 0.123 & 0.127 & 253.10 & 1.64 & 0.39 \\
\hline A. filiculoides & 2.82 & 730.0 & 5.43 & 5.34 & 0.126 & 0.130 & 264.30 & 1.69 & 0.36 \\
\hline $\begin{array}{l}\text { Azolla hybrid } \\
\text { Rong ping }\end{array}$ & 3.11 & 810.0 & 5.39 & 5.02 & 0.129 & 0.136 & 318.20 & 2.01 & 0.64 \\
\hline $\begin{array}{l}\text { Azolla hybrid } \\
\text { TNAU1 }\end{array}$ & 2.97 & 790.0 & 5.41 & 5.14 & 0.127 & 0.134 & 303.10 & 1.86 & 0.51 \\
\hline CD (5\% & .14 & 10.4 & 0.08 & .04 & 005 & 008 & 4.70 & 0.08 & 0.06 \\
\hline
\end{tabular}

Table.2 Effect of feeding the Azolla hybrid Rong ping on the productivity in Layer birds

\begin{tabular}{|c|c|c|c|c|c|c|c|}
\hline \multirow{2}{*}{$\begin{array}{l}\text { Age in } \\
\text { week }\end{array}$} & \multicolumn{3}{|c|}{ \#Egg Productivity (\%) } & \multicolumn{4}{|c|}{ \# \#Concentrated feed intake (g/day/bird) } \\
\hline & $\begin{array}{c}\text { Azolla } \\
\text { fed birds }\end{array}$ & $\begin{array}{c}\text { Contr } \\
\text { ol }\end{array}$ & $\begin{array}{c}\% \\
\text { increase } \\
\text { over } \\
\text { control }\end{array}$ & $\begin{array}{c}\text { Azolla } \\
\text { fed } \\
\text { birds }\end{array}$ & Control & $\begin{array}{l}\text { Savings in the } \\
\text { concentrated } \\
\text { feed } \\
\text { (g/day/bird) }\end{array}$ & $\begin{array}{l}\text { \% savings } \\
\text { in the } \\
\text { concentrat } \\
\text { ed feed }\end{array}$ \\
\hline 51 & 93.0 & 84.7 & 9.80 & 106 & 132 & 26.0 & 19.6 \\
\hline 52 & 91.5 & 86.3 & 6.00 & 106 & 132 & 26.0 & 19.8 \\
\hline 53 & 87.2 & 83.9 & 3.90 & 92 & 132 & 40.0 & 30.5 \\
\hline 54 & 89.7 & 83.6 & 7.20 & 109 & 119 & 10.0 & 8.52 \\
\hline 55 & 88.0 & 85.9 & 2.43 & 109 & 121 & 12.0 & 10.0 \\
\hline 56 & 90.6 & 71.2 & 27.1 & 108 & 107 & - & - \\
\hline 57 & 91.1 & 82.3 & 10.7 & 102 & 124 & 22.0 & 17.6 \\
\hline 58 & 87.8 & 79.2 & 10.9 & 114 & 121 & 7.0 & 6.03 \\
\hline 59 & 89.7 & 80.4 & 11.5 & 101 & 116 & 15.0 & 13.0 \\
\hline 60 & 86.6 & 81.4 & 6.40 & 106 & 120 & 14.0 & 11.7 \\
\hline 61 & 87.8 & 83.6 & 5.05 & 103 & 126 & 23.0 & 17.9 \\
\hline 62 & 88.1 & 84.7 & 4.04 & 99 & 118 & 19.0 & 16.2 \\
\hline 63 & 89.4 & 85.7 & 4.25 & 116 & 120 & 4.00 & 3.04 \\
\hline 64 & 92.7 & 90.3 & 2.65 & 106 & 118 & 12.0 & 10.0 \\
\hline 65 & 80.8 & 81.1 & - & 105 & 117 & 12.0 & 9.50 \\
\hline 66 & 90.3 & 89.7 & 0.62 & 107 & 121 & 14.0 & 11.3 \\
\hline 67 & 89.1 & 88.6 & 0.50 & 106 & 118 & 12.0 & 10.8 \\
\hline Average & 89.0 & 83.7 & 6.64 & 106 & 122 & 16.0 & 13.0 \\
\hline$t=1 \%$ & $4.73^{* *}$ & & & $\mathrm{t}=5 \% 6.77^{*}$ & & & \\
\hline
\end{tabular}


Table.3 Effect of Azolla hybrid Rong Ping on the nutritional value* of egg

\begin{tabular}{lccc}
\hline \multicolumn{1}{c}{ Parameters } & Azolla egg & Control & $\begin{array}{c}\text { \% increase over } \\
\text { control }\end{array}$ \\
\hline Egg weight $(\mathrm{g})$ & 61.20 & 57.40 & 6.62 \\
Albumin $(\mathrm{g} / 100 \mathrm{~g}$ of edible portion) & 3.9 & 3.4 & 14.70 \\
Globulin $(\mathrm{g} / 100 \mathrm{~g}$ of edible portion) & 10.1 & 9.5 & 6.31 \\
Total protein $(\mathrm{g} / 100 \mathrm{~g}$ of edible portion) & 14.0 & 12.9 & 8.52 \\
Carotenes $(\mu \mathrm{g} / 100 \mathrm{~g}$ of edible portion) & 440 & 405 & 8.64 \\
\hline
\end{tabular}

*Values represent mean of three replications

The total protein content of the eggs laid by the Azolla fed birds was high $(14.0 \mathrm{~g} / 100 \mathrm{~g})$ and the total carotene content of Azolla egg (440 $\mu \mathrm{g} / 100 \mathrm{~g}$ of edible portion) was also higher than the control. Ali and Leeson (1995) found that the addition of Azolla powder to poultry feed significantly improved the carotene status of the chicken and increased egg production.

In conclusion, the rapid biomass production due to high relative growth rate, increased protein, carotene and $\beta$ carotene contents and good digestibility of the Azolla hybrid Rong ping favoured its use as an effective feed supplement to poultry birds. In Indian conditions, agriculture is very much coupled with poultry farming. Azolla is an important low cost input, which plays a vital role in improving soil quality in sustainable rice farming (Kannaiyan, 1995). The twin potential as biofertilizer and animal feed make the water fern Azolla as an effective input to both the vital components of integrated farming, agriculture and animal husbandry.

\section{Acknowledgement}

The authors are thankful to the Indian Council of Agricultural Research, New Delhi for financial support extended to carry out this work under National Agricultural Technology Project - Team of Excellence on Biofertilizers for rice based cropping system.

\section{References}

Ali and Leeson. 1995. Nutritive value of some indigenous Asian poultry feed ingredients. Animal Feed Science Technology. 55: 227-37.

Anon. 1985. Propagation and agricultural use of Azolla in Vietnam. International Rice Communication Newsletter 34: 79.

Becking J H. 1979. Environmental requirements of Azolla for use in tropical rice production. (In) Nitrogen and Rice, International Rice Research Institute, Philippines, Pages 345-75.

Ivan D T and Thuget T Q. 1989. Use of Azolla in rice production in Vietnam. (In) Nitrogen and Rice, International Rice Research Institute, Philippines, Page 395.

Kannaiyan S. 1988. Potentiality of Azolla biofertilizer for rice. (In) soil Biology, Mishra M M and Kapoor K K (Eds). Haryana Agrl. Univ. Hisar, Pages 253-59.

Kannaiyan S.1992. Azolla Biofertilizer Technology for Rice. Technical bulletin, Tamil Nadu Agricultural University, Coimbatore, Tamil Nadu, Page 56.

Kannaiyan S. 1995. Biofertilizers for rice: Status and scope. (In) Rice Management Biotechnology, Kannaiyan S (Ed). Associated Publishing Company, New Delhi, Pages 237-65.

Lowry O H, Robebrough N J, Larr A L and Randall R I. 1957. Protein measurement with folin phenol reagent. Journal of 
Biological Chemistry. 193: 265-75.

Siegelman H W and Kycia J H. 1976. Hand book of physiological and biochemical methods, Helle Bust J A and Craigie J S. (Eds). Cambridge University Press, Cambridge, Pages 71-79.

Sundararaju V, Prabakaran R, Ahmed M, Abdul Mujeer K, Sundaravarathan S and Kannaiyan S. 1995. Effect of feeding Azolla, Sesbania and Leucaena proteins on broiler performance. National workshop on Algal and Azolla biofretilizers, Tamil Nadu Agricultural University, Coimbatore, Tamil Nadu., Page 84.
Subudhi B P R and Watanabe I. 1981. Differential phosphorus requirement of Azolla species and strains in phosphorus limited continuous culture. Soil Science and Plant Nutrition. 27: 237-47.

Tyagi V V S, Mayne B C and Peters G A. 1980. Purification and initial characterization of phycobiliproteins from the endophytic cyanobacterium of Azolla. Archives of Microbiology. 128: 41-44.

Watanabe I. 1977. Azolla utilization in rice culture. International Rice Research Newsletter 3: 10.

\section{How to cite this article:}

Lakshmanan, A., K. Kumar and Latha, P. 2017. Azolla - A Low Cost and Effective Feed Supplement to Poultry Birds. Int.J.Curr.Microbiol.App.Sci. 6(8): 3622-3627. doi: https://doi.org/10.20546/ijcmas.2017.608.436 